This is an author produced version of a paper published in Forest Ecology and Management.

This paper has been peer-reviewed and is proof-corrected, but does not include the journal pagination.

Citation for the published paper:

Brukas, V., Felton, A., Lindbladh, M. \& Sallnäs, O.. (2013) Linking forest management, policy and biodiversity indicators - a comparison of Lithuania and southern Sweden. Forest Ecology and Management. Volume: 291, pp 181189.

http://dx.doi.org/10.1016/j.foreco.2012.11.034.

Access to the published version may require journal subscription.

Published with permission from: Elsevier.

Standard set statement from the publisher:

this is the author's version of a work that was accepted for publication in Forest Ecology and Management. Changes resulting from the publishing process, such as peer review, editing, corrections, structural formatting, and other quality control mechanisms may not be reflected in this document. Changes may have been made to this work since it was submitted for publication. A definitive version was subsequently published in Forset Ecology and Management, 291, (March 2013) 10.1016/j.foreco.2012.11.034

Epsilon Open Archive http://epsilon.slu.se 


\title{
Linking forest management, policy and biodiversity indicators - A comparison of Lithuania and Southern Sweden
}

\author{
Vilis Brukas ${ }^{1}$ (Corresponding author), Adam Felton ${ }^{1}$, Matts Lindbladh ${ }^{1}$, Ola Sallnäs ${ }^{1}$ \\ ${ }^{1}$ Swedish University of Agricultural Sciences \\ Southern Swedish Forest Research Centre \\ Box 49; 23053 Alnarp; Sweden \\ phone: +46 40415198 \\ mobile: +46705453499 \\ fax: +46 40462325 \\ e-mails: vilis.brukas@slu.se, adam.felton@slu.se, matts.lindbladh@slu.se, ola.sallnas@slu.se
}

\section{Linking forest management, policy and biodiversity indicators - A comparison of Lithuania and Southern Sweden}

\begin{abstract}
Lithuania and Southern Sweden share similar natural conditions, but differ considerably in forest policies and management; thereby providing an opportune basis for comparative studies. Since the 1990s, Sweden has attempted to reduce the negative impact of its forest management on biodiversity, after decades of intensive production forestry. In contrast, Lithuania has been intensifying forestry practices associated with the post-soviet socioeconomic transition. Here we assess the actual outcomes by comparing selected forest structure and composition variables known to be indicators for forest biodiversity; and estimate the prospective trends by scrutinising current forest policies and management. Our results indicate that Lithuanian forests consistently possessed higher rankings in six indices related to tree species composition, stand age, and deadwood quantities that are positively associated with forest biodiversity. The reverse is indicated by those data on stand age and tree diameter that are associated with centennial dynamics in forest utilisation intensity. With respect to policy instruments, Lithuania designates a substantially greater share of forest area to non-timber functions and legislates more severe management restrictions in forests targeting timber production. Concurrently, all estimates of forestry activities indicate more intensive forest management in Southern Sweden, including a higher share of artificial regeneration and shorter rotations. This allows concluding that, if current forest management practices persist, then an increased "biodiversity gap" may be expected between the two countries. The study concludes with discussing to what degree the identified trends are the direct product of targeted policies versus merely by-products of other factors.
\end{abstract}

Keywords: Lithuania, Götaland, segregative management, integrative management, policy instruments, national forest inventory, structural indicators.

\section{Introduction}

The countries situated on the shores of the Baltic Sea offer a unique opportunity for comparative research into the combined influences of distinct land-use histories on forest biodiversity (Angelstam et al., 1997, 2001). Whereas the shared bio-geographical setting of the Baltic region results in a relatively consistent latitudinal gradient in forest biomes (Ahti et al., 1968), the different political and economic histories of these proximate countries result in a distinct longitudinal divide (Maciejewski, 2002). The managed forests of Sweden and Lithuania are indicative of such contrasts. 
Lithuania and Sweden have extensive areas of hemiboreal forests, which provide one of the primary natural resources for both countries. Distinct differences exist however in the forest management goals, utilisation histories, ownership structures, and production efficiencies of their respective forest sectors (Balkyte and Peleckis, 2010; Brukas and Weber, 2009; Brukas and Sallnäs, 2012). The Swedish sector is characterised by a stable long-term development of institutions and practices (Enander, 2007), with vertically integrated forest sector, cutting-edge forestry technologies and a silvicultural focus on sustaining discounted profits, the latter driving towards economically optimal rotation ages. A policy shift aimed at a more even balance between timber production and environmental values took place in early 1990s (Bush, 2010). The "Swedish forestry model" has subsequently been promoted as giving a large space for owner's silvicultural decisions while at the same time being responsive to societal needs, more specifically, an increased environmental consideration (KSLA, 2009). It was acclaimed for integrating nature conservation measures in timber-producing stands in combination with set-asides at higher spatial scales (Gustafsson and Perhans, 2010). Sweden has nevertheless maintained an intensive utilisation by European standards, with the annual timber harvest equating with an average gross increment ratio of $70 \%$, both before and after the relevant policy shifts of the early 1990s (SKS, 2011).

In contrast, Lithuanian forestry was exposed to radical societal transition after Lithuania broke away from the Soviet Union in 1990, bringing about, inter alia, free markets, privatisation, and institutional reforms (Lazdinis et al., 2009). Lithuanian forests are still to a large extent managed without consideration of interest rates, instead maximising volume production of valuable timber assortments (Brukas and Weber, 2009). However, the introduction of free markets, along with other factors, led to a doubling in utilisation intensity (Brukas and Kairiūkštis, 2003; Brukas et al., 2009). Disregarding forests reserved for the restitution of the private property, the annual harvesting/increment ratio has over the last decade approached Swedish levels, and averaged approximately 65\% in 1997-2007 (Brukas et al., 2011).

It has long been recognized that the lower management intensity found in many of the countries previously under the centralized control of the Soviet Union, helped to contribute to the retention of higher forest biodiversity values relative to their West European counterparts (Angelstam et al., 1997). For example, there is a clear positive geographical gradient from the west to east in Europe in amount of pristine forest remaining (Angelstam et al., 2001). With the fall of the Soviet Union in 1990, several authors have raised concerns that the shift to a market-economy criteria of maximising their forest's net present value could dramatically alter Lithuania's forest landscape, with associated negative impacts on forest dependent taxa (Angelstam et al., 1997; Hjortso and Straede, 2001; Kurlavičius et al., 2004). This concern has been revitalized in Lithuania in recent years, because of calls for privatisation of Lithuania's state forests, and a general push for increased competitiveness and efficiency of the forest sector (Balkyte and Peleckis, 2010).

Has the Swedish forest policy shift towards "greening" led to more environmentally sensitive forestry practices and better environmental outcomes compared to Lithuania that has intensified its forestry during the socio-economic transition? The study aims to answer this question by comparing the current forest state, policy instruments and actual forest management practices. Most research to date either examines forest biodiversity per se (occasionally linking it to forest management practices); or conducts policy analyses detached from the actual forest management. In this multidisciplinary study we attempt to overlay these different facets to enable a comprehensive comparison. The paper concludes by discussing to what degree forest 
management impacts on biodiversity are a consequence of targeted policies for environmental conservation.

\section{Materials and methods}

\subsection{Studied regions}

In Sweden we select the Götaland region that occupies the southern one-fifth of the country's territory and features natural conditions most closely approximating those in Lithuania. Nonindustrial private forest owners prevail in Götaland, covering $78 \%$ or approximately 4 million ha of the total forest area (SKS, 2011). Lithuanian state forest enterprises own 50\% (circa 1 million ha) of forests, $39 \%$ are in hands of private forest owners, while $11 \%$ are still reserved for the restitution (MERL, 2011).

Table 1. Selected indicators for Lithuania and Southern Sweden (Götaland).

\begin{tabular}{|c|c|c|}
\hline & Lithuania & Götaland \\
\hline $\begin{array}{l}\text { Forest area }{ }^{1} \text {, million ha (share in the total } \\
\text { land area) }\end{array}$ & $2.2(34 \%)$ & $4.9(58 \%)$ \\
\hline Forest area per inhabitant ${ }^{1}$, ha & 0.72 & 0.92 \\
\hline $\begin{array}{l}\text { Dominant forest species }{ }^{1} \text { (their shares in } \\
\text { the total volume) }\end{array}$ & $\begin{array}{r}\text { Scots pine }(37 \%), \\
\text { Norway spruce }(20 \%), \\
\text { birch }(17 \%)\end{array}$ & $\begin{array}{r}\text { Norway spruce }(48 \%), \\
\text { Scots pine }(30 \%), \\
\text { birch }(10 \%)\end{array}$ \\
\hline $\begin{array}{l}\text { Gross annual stem wood increment }{ }^{1}, \\
\mathrm{~m}^{3} / \mathrm{ha}^{\text {year }}\end{array}$ & 7.9 & 6.9 \\
\hline Mean annual temperature ${ }^{2},{ }^{\circ} \mathrm{C}$ & 6.1 & 6.5 \\
\hline $\begin{array}{l}\text { Annual precipitation, average (regional } \\
\text { variation) }{ }^{2}, \mathrm{~mm}\end{array}$ & $675(603-820)$ & $740(600-987)$ \\
\hline
\end{tabular}

Sources:

1Estimates for 2011 from (MERL, 2011; SKS, 2011; LSD, 2011; Statistiska Centralbyrån, 2011) ${ }^{2}$ Climate normal data for 1961-1990 from (Satkūnas, 2011) for Lithuania and calculated from county statistics (SMHI, 2012) for Götaland.

The two studied regions feature similar climatic conditions (Table 1). Forest soils are not directly comparable due to differences in the soil classification systems. However, historic data on natural tree species compositions may well serve for juxtaposing the virgin conditions. The forest composition during mid- and late-Holocene was very similar in Lithuania and Southern Sweden (Stančikaitè et al., 2004; Kabailienè, 2006; Lindbladh and Foster, 2010). The temperate broadleaves trees (oak, ash, elm, etc) were more common in the past than today, and to both countries there was a late immigration of spruce, however somewhat earlier to Lithuania than to Sweden. These circumstances indicate that human impacts, rather than variability in natural conditions, could be the most important factor behind potential differences in biodiversitysupporting forest stand structures.

\subsection{Overview of methodology}

The legacy of historic land use patterns and forestry practices is exhibited in the current state of a region's forests. We start our analysis by scrutinising current forest conditions in Lithuania and Götaland using a set of widely accepted biodiversity indicators that can be acquired for each of the study regions. Second, we analyse policy instruments that steer forest management, both in terms of spatially dividing management regimes between different forest stands (segregative management) and in terms of combining various management aims on the same forest stand (integrative management). Finally, we look at current forest management practices in commercial forests of the studied regions. This reveals how the legal stipulations and voluntary instruments 
translate into actual management; and provides an indication of how forest biodiversity might be affected in coming years.

\subsection{Forest condition indicators}

In assessing the forest characteristics, we resort to national forest inventories (NFIs) that are the most reliable and systematically updated sources of data on forest conditions. Timber production traditionally was the core focus of NFI and data were often difficult to compare internationally due to different NFI designs, variation of assessed criteria, etc. In recent years, many NFIs were expanded to more comprehensibly assess multiple forest functions and considerable attempts were made to harmonise the data between countries (Chirici, 2011; Tomppo, 2010). Lithuania and Sweden conduct NFIs of comparable design (Tomppo, 2010), although some potentially important data are missing either in one, or in both countries. For example, the Swedish NFI does not survey shrubs, while Lithuanian NFI has not yet compiled data enabling comparison of decay classes of deadwood. In some cases the same data are collected but organised in different ways, e.g. tree diameter classes are reported differently; or harmonisation may be unfeasible due to differences in definitions. For example, vertical forest structure is not comparable, as the Lithuanian and Swedish NFIs single out tree layers based on different threshold values for height differences between layers, and with respect to the minimum basal area of a layer.

Numerous empirical studies have examined forest biodiversity and used such results to provide widely applicable indicators of biodiversity values based on various aspects of forest structure and composition. A common approach to "measuring" biodiversity is to estimate the abundance of chosen species or taxa, often focusing on "umbrellas" or "indicators" covering large number of cooccurring species and thus serving as proxies for valuable habitats, (cf. Roberge and Angelstam, 2004). However, structural indicators are generally found to be superior to species-based indicators since, among other concerns, relationships between potential indicator species and biodiversity are not well established; recording selected species does not necessarily provide insights in how to improve management; and such records are generally of poor quality (Lindenmayer et al., 2000; McElhinny et al., 2005).

For the outlined reasons we base our comparison on indicators relating to structural features of forest stands (McElhinny et al., 2005). We select a set of indicators each of which should be: (i) evidently correlating with the level of biodiversity; (ii) easy to interpret; (iii) based on data that are retrievable from archived sources within a reasonable time input; and (iv) enable fair comparison between the case regions. Such selection principles capture many of the characteristics for judging indicator quality as elaborated by Duinker (2001), including relevance, practicality, understandability and measurability.

In their extensive review, McElhinny et al. (2005) identify the following stand elements utilised as structural indicators for forest biodiversity: foliage, canopy cover, tree diameter, tree height, tree spacing, stand biomass, tree species, understorey vegetation, and deadwood. Applying our selection criteria, foliage, tree spacing and stand biomass can be excluded from analysis because their correlation with biodiversity is not sufficiently established and often difficult to interpret (criteria (i) and (ii)). Further, attributes of foliage, canopy cover, tree spacing and understorey vegetation are either difficult to retrieve with reasonable time input (iii) or impossible to harmonise for the comparison between case regions (iv), as was illustrated in the description of the data sources. Data on tree height are available, however the height correlates with tree diameter and age that are more straightforward indices for biodiversity (e.g. Fritz et al., 2009). 
Application of our selection criteria yielded the set of indicators referring to three main forest condition parameters, namely tree species composition, tree age/diameter, and amount of deadwood (Table 2). These cover a significant share of the structural indicators that the EU Cost Action on harmonisation of NFIs in Europe identified to be of high or very high importance for forest biodiversity (Corona and Marchetti, 2007). Specific attributes for each indicator (Table 3) are identified via refining and quantifying the selected indicators using the same criteria (i)-(iv), however with emphasis on the capacity to retrieve harmonised data.

Table 2. Selected indicators for assessing forest condition in Lithuania and Southern Sweden, and their empirical justification from the ecological literature providing.

\begin{tabular}{|c|c|c|}
\hline Indicator & Features in favour to biodiversity & $\begin{array}{l}\text { Scientific support for } \\
\text { indicator }\end{array}$ \\
\hline $\begin{array}{l}\text { Tree species } \\
\text { composition }\end{array}$ & $\begin{array}{l}\text { Broadleaved species and broadleaf- } \\
\text { conifer mixtures superior to conifer } \\
\text { monocultures }\end{array}$ & $\begin{array}{l}\text { Jonsell et al., 1998; Jansson and } \\
\text { Angelstam, 1999; Kouki et al., } \\
\text { 2004; Lindenmayer and Hobbs, } \\
\text { 2004; Carnus et al., 2006; } \\
\text { Brockerhoff et al., 2008; Felton } \\
\text { et al., } 2010\end{array}$ \\
\hline $\begin{array}{l}\text { Stand or tree age } \\
\text { and dimension }\end{array}$ & $\begin{array}{l}\text { Older age and larger tree diameters } \\
\text { favoured }\end{array}$ & $\begin{array}{l}\text { Berg et al., 1994; Nilsson et al., } \\
\text { 2001; Liira et al., 2007; Jonsell } \\
\text { et al., } 1998\end{array}$ \\
\hline Amount of deadwood & $\begin{array}{l}\text { Larger amounts of deadwood, especially } \\
\text { coarser dimensions favoured }\end{array}$ & $\begin{array}{l}\text { Ohlson et al., 1997; Martikainen } \\
\text { et al., 2000; Jonsson and Kruys, } \\
\text { 2001; Jonsson et al., 2005; }\end{array}$ \\
\hline
\end{tabular}

\subsection{Policy instruments}

A variety of policy instruments may be applied for steering forest management. This study spotlights those instruments that set norms by stipulating management regimes in the case of segregated management (forestland zoning); and those that specify permissible thresholds for integrative forest management activities in forests aimed at timber production.

As for the segregative management, we examine the latest development of forestland zonation in each study region. The ultimate focus is on comparing the distribution of forest area within distinct management zones setting varying levels of restrictions on forestry. We also examine the degree of coerciveness in implementing the segregative management.

In the integrative management a set of management goals and measures is used for the same forest stand to enhance non-timber ecosystem services within the matrix of forests devoted to timber production. We compare legal stipulations for the main silvicultural activities during a typical forest rotation, i.e. focusing on regeneration techniques, thinning regimes and final felling procedures. In Lithuania, the most relevant provisions are given in the Forest Act (LRS, 2011) and several forestry regulations (MERL, 2007; MERL, 2008; MERL, 2010a). In Sweden, relevant prescriptions are compiled in the Swedish Forestry Act (LD, 1993). In addition to legal requirements, provisions for national forest certification standards have influenced forest management, both in public and private forests (Schlyter et al., 2011; Brukas and Sallnäs, 2012). Of the two current systems, Forest Stewardship Council (FSC) and Programme for Endorsement of Forest Certification (PEFC), we chose to analyse FSC (FSC Sweden, 2010). Covering about $60 \%$ of the productive forest area in Sweden, FSC takes the largest share of the certified land and has more stringent requirements than PEFC. We do not consider forest certification in Lithuania. The main reason is that our review of standards revealed rather minor differences from Lithuanian legislation. 


\subsection{Forest management practices}

While regulatory instruments set permissible regimes and thresholds, these do not have to coincide with the actual management practices. Our study compares the latest estimates of the common forestry practices as well as their trends over the last two decades. Similarly to forest condition indicators, the selection of attributes was based on: evidence of considerable and unequivocal impact of respective management practices on forest biodiversity (Hartmann et al., 2010); and the feasibility of extracting data that are comparable between the studied regions. NFI data turned out to be much more limited in terms of information on management practices compared with that provided for forest condition indicators; therefore this component of data collection was extended to include additional sources (provided under Table 6). The focus of which was on comparing forestry measures on the stand level, i.e. silvicultural treatments in connection with forest regeneration, thinnings, and final fellings.

Table 3. Comparison of forest condition indicators of relevance to biodiversity

\begin{tabular}{|c|c|c|c|c|}
\hline \multirow[t]{2}{*}{ FOREST CONDITION INDICATORS and respective attributes } & \multicolumn{2}{|c|}{ Lithuania } & \multicolumn{2}{|c|}{ Götaland } \\
\hline & $\begin{array}{c}\text { Esti- } \\
\text { mate }^{1}\end{array}$ & $\mathrm{SE}^{2}$ & $\begin{array}{c}\text { Esti- } \\
\text { mate }^{1}\end{array}$ & $\mathrm{SE}^{2}$ \\
\hline \multicolumn{5}{|l|}{ TREE SPECIES COMPOSITION } \\
\hline$\%$ of deciduous trees in the total standing volume & 42.9 & 0.7 & 24.0 & 0.7 \\
\hline$\%$ of noble deciduous trees in the total standing volume & 6.5 & 0.3 & 7.6 & 0.5 \\
\hline$\%$ of deciduous tree volume in conifer stands ${ }^{3}$ & 10.7 & 0.3 & 7.5 & 0.3 \\
\hline$\%$ of native tree species in the total standing volume & 99.9 & 1.3 & 99.8 & n.a. \\
\hline Number of native tree species that make $>5 \%$ of the total volume & 5 & n.a. & 3 & n.a. \\
\hline \multicolumn{5}{|l|}{ STAND AGE } \\
\hline $\begin{array}{l}\% \text { of } \geq 120 \text { years age stands in the total area of conifer-dominated } \\
\text { stands }\end{array}$ & 2.4 & 0.2 & 5.8 & 0.4 \\
\hline $\begin{array}{l}\% \text { of } \geq 80 \text { years age stands in the total area of conifer-dominated } \\
\text { stands }\end{array}$ & 23.5 & 0.6 & 23.2 & 0.7 \\
\hline $\begin{array}{l}\% \text { of noble deciduous stands in the total area of noble deciduous } \\
\text { stands, } \geq 150 \text { years in Lithuania and } \geq 160 \text { years in Götaland }\end{array}$ & 6.2 & 1.1 & 1.0 & 0.6 \\
\hline \multicolumn{5}{|l|}{$\begin{array}{l}\text { STRUCTURAL INDICATORS } \\
\text { Number of living trees with breast height diameter, trees/1000 } \\
\text { ha }\end{array}$} \\
\hline$\geq 70 \mathrm{c}$ & 163 & n.a. & 190 & n.a. \\
\hline$\geq 50$ & 3126 & n.a. & 2576 & n.a. \\
\hline Amount of deadwood, $\mathrm{m}^{3} / \mathrm{ha}$ & 9.0 & 0.2 & 7.7 & 0.3 \\
\hline $\begin{array}{l}\text { Number of dead trees } / 1000 \text { ha with breast height diameter } \\
\text { exceeding } 38 \mathrm{~cm} \text { in Lithuania and } 39 \mathrm{~cm} \text { in Sweden }\end{array}$ & 500 & 44 & 188 & n.a. \\
\hline
\end{tabular}

Notes:

${ }^{1}$ Indicators represent the forest state in 2008 or later based on data from the national sampling-based forest inventories (SFSS, 2009; SKS, 2009; TaxWebb, 2011) or data extracted on special requests by NFI experts.

2The presented standard errors (SE) should be regarded as only indicative. They are calculated from published figures for other aggregates (Toet et al., 2007; SFSS, 2009)

${ }^{3}$ Conifer-dominated: refer to stands where volume of conifers makes $\geq 50 \%$ of the volume.

\section{Results}

\subsection{Forest condition}

As part of our analysis we make the assumption that Norway spruce (Picea abies) is native to the whole of Sweden. We emphasize this point because its nativeness could be questioned with respect to the narrow temperate part of Götaland (Hesselman \& Schottte 1906. Native 
species overwhelmingly dominate forests of Götaland and Lithuania (Table 3). Conifer monocultures clearly prevail in the forest landscapes of Götaland, while Lithuania has a higher proportion of production forests composed of broadleaf-dominated stands and higher proportion of a variety of broadleaf species within otherwise conifer-dominated stands. On the other hand, the proportion of the temperate broadleaves, oak (Quercus robur), beech (Fagus sylvatica), maple (Acer platanoides), elm (Ulmus spp.), ash (Fraxinus excelsior), lime (Tilia cordata) hornbeam (Carpinus betulus) and wild cherry (Prunus avium), is higher in Sweden. Beech is the tree species that makes the largest difference among the noble species, constituting $2.2 \%$ of the total standing volume in Götaland, but is almost absent in Lithuania, which is outside of its natural range.

Götaland has a considerably higher share of conifer stands above 120 years and a higher number of trees exceeding $70 \mathrm{~cm}$ breast height diameter. This situation is reversed for the share of old temperate deciduous trees. Also Lithuanian forests harbour higher a amount of deadwood, in particular for the larger dimensions.

\subsection{Policy instruments steering management}

\subsubsection{Segregative management (forestland zoning)}

In terms of forestland zoning, two parallel systems are in place in Lithuania, namely, the system of protected areas (PAs), and forestland division into so-called functional forest groups. PAs make up 15\% of the country's territory (MERL, 2010b), encompassing strict nature reserves, national and regional parks, state and municipal reserves, and other categories. Forests cover $70 \%$ of all PAs, corresponding to 707,000 hectares. Irrespective of whether a particular forest falls under a PA or not, each forest stand is assigned to one of four forest groups (LRS, 2011): I (strict reserves) left for natural development; II (protected and recreational forests) managed with the aim of conserving environmental values, or to form attractive recreational environments; III (protective forests) aimed at forming productive stands with high capacity to protect soil, air, water or urban areas; and IV (exploitable or commercial forests) productive stands primarily aimed at ensuring sustainable timber flow.

Forest groups are convenient for assessing segregative restrictions as certain management constraints are attached to each group irrespective of its PA status, if any. To facilitate the comparison, the groups can be aggregated into two main classes. On 290,000 ha, belonging to groups I and II (13\% of the total forest area), forest management is heavily restricted (Table 4). Timber extraction in the form of thinnings is possible, however, with the primary purpose to enhance the nature or recreational values. The actual timber harvesting/increment ratio in 1998-2007 for this group did nevertheless constituted 30\% (Brukas et al. 2011). Thus, we include in this category stands in which some timber is removed, but the management is nevertheless primarily aimed at promoting environmental values both as formally stated aims, and as dictated by the silvicultural measures applied.

As noted above, despite differences in the stated management goals, permissible forest activities and resulting management intensities are similar for groups III and IV. Thus the respective $87 \%$ of forest area can be defined as commercial forests with timber production as the primary function.

Strict reserves (group I) can only occur in state forests, but severe restrictions do apply in the private forests belonging to group II. The division of forestlands into forest groups was accomplished in 1995, during the starting phase of forest restitution, i.e. the process of returning forests to the pre-war landowners or their heirs. Forest categorization was imposed by state authorities, without forest owners having influence over the outcome. Thus the land- 
use status and the associated levels of restrictions turned out to be a matter of luck for an owner, depending on how congruent the imposed regimes were with the owner's goals.

Table 4. Distribution of forest area by forest groups and ownership in Lithuania, 2010.01.01

\begin{tabular}{llrrr}
\hline Forest group & \multicolumn{1}{c}{ Management regime } & \multicolumn{3}{c}{ Share of forest by ownership, \% } \\
\cline { 3 - 5 } & & $\begin{array}{c}\text { State } \\
\text { Private \& } \\
\text { reserved }\end{array}$ & \multicolumn{1}{c}{ All } \\
\hline $\begin{array}{l}\text { I. Strict reserves } \\
\text { II. Protected \& } \\
\text { recreational }\end{array}$ & $\begin{array}{l}\text { No cuttings allowed } \\
\text { allowed at the age of natural maturity }\end{array}$ & 15.0 & 0.5 & 1.2 \\
\hline III. Protective & $\begin{array}{l}\text { Clear fellings of reduced size allowed at } \\
\text { higher ages, compared with group IV } \\
\text { All types of fellings allowed, according to }\end{array}$ & 11.3 & 19.6 & 15.5 \\
IV. Exploitable & 71.2 & 70.9 & 71.1 \\
\hline All groups & & 100 & 100 & 100 \\
\hline
\end{tabular}

Sweden does not employ a comparable uniform system of dividing forestland into functional groups. It is however possible to separate two main land zone classes, namely: (i) forests that are set aside or managed for a primary purpose other than timber production, and (ii) forests primarily managed for timber. Forests of national parks and nature reserves constitute the core of the Swedish PA system, occupying 83,000 ha of productive forestland area in Götaland as of 2009 (SKS, 2011). Since the 1990s the Swedish state employs compensatory payments to forest owners, for either a permanent withdrawal of forestland from timber production (so-called habitat protection areas, accumulated to 6,700 ha in 2010), or temporary management restrictions valid for up to 50 years (nature conservation agreements, 9,200 ha in 2010). Adding these together, the total area with formal forest management restrictions of comparable degree to Lithuanian forest groups I and II constituted approximately $1.9 \%$ of the total productive forestland in Götaland.

Since the mid 1990s, Swedish forestland zoning has been also evolving with respect to voluntary protection and forest certification. Wishing to certify a forest estate in excess of 20 ha, the owner needs to arrange a management plan that divides the forestland into so-called goal classes. These are strikingly similar to the Lithuanian forest groups, including strict set asides (Swedish abbreviation: NO), forests managed for nature values (NS), forests managed for timber production but with increased consideration for nature values (PF), and forest managed for timber production with general nature consideration, i.e. following the legislative requirements for commercial forests (PG). To get a certificate, at least $5 \%$ of forest area on an estate must be designated NO or NS. Emergence of price premiums for certified timber has been the major factor underlying the increased certification of private family forest estates (Brukas and Sallnäs, 2012) and, in turn, the area of forest under NS and NO categories. Such voluntarily protected forests make up 187.000 ha (SKS, 2011), which corresponds to $3.7 \%$ of productive forest area in Götaland.

Voluntary protection entails a risk that the owner might change their mind and resort to intensive management for timber at some point in the future. In addition the estate may be sold without the voluntary commitments passing over to the new owner. According to the recent evaluation of national environmental objectives (Naturvårdsverket, 2012), an estimated $75 \%$ share of forest owners claim that they would maintain the voluntary setasides for more than 30 years. Even assuming that all estates will maintain the protection status, formally and voluntary protected productive forests add up to $4.8 \%$ of the total productive forestland in Götaland, compared to the $13.4 \%$ of the protected forestland categorized as groups I and II in Lithuania. 


\subsubsection{Integrative management}

Lithuanian legislation echoes the long-standing silvicultural tradition of site-adapted management. Since the Soviet times, silvicultural regulations prescribed tree species and methods of forest regeneration for each site type, with the underlying aim to reach high timber production. It was not until 2008 that a legislative shift occurred towards the less rigorous specification of regeneration methods, though the defined target species were still recommended to constitute more than $50 \%$ of the regenerated stand (MERL, 2008). The previous requirement to regenerate harvested stands of oak, maple, lime and pine (Pinus sylvestris) with the same species was removed arguing that it contradicted the principles of natural succession (Bitvinskaitè, 2011). The current legislation does retain owner obligations to regenerate felling sites within 3 years after harvest (Table 5), and puts stringent requirements on planting material, giving priority to material of regional genetic origins (MERL, 2007). The Swedish Forest Act of 1993 guides forest regeneration rather more liberally, with the main aim to achieve satisfactory timber production. Environmental concerns are reflected however in stipulations for tree species composition. Stands of temperate broadleaves (oak, beech, ash (Fraxinus excelsior), elm (Ulmus spp.), hornbeam (Carpinus betulus), lime, maple and wild cherry (Prunus avium) need to be regenerated with noble broadleaves. On sites exceeding 0.5 ha, exotic species can only be used in "exceptional cases", without further specification of the thresholds and circumstances under which "the exceptional" may be encountered. In contrast to the law, the Swedish FSC standard put a maximum 5\% area limit for establishing exotic species. This standard also includes qualitative stipulations for environmental measures, e.g. restricting soil preparation to sites where such treatments are necessary to achieve successful regeneration, and using intermittent methods of site preparation on moist soils.

The ultimate goal of Lithuanian thinning regimes is to achieve maximum possible timber stocking of the desired species throughout the rotation. Legislation provides detailed provisions for thinnings depending on trees species composition, site conditions, mean tree height and diameter and stocking index. Cutting Regulations of 2010 introduced a prohibition on thinning during the bird-breeding season. In contrast, the Swedish Forest Act (1993) does not regulate thinning activities in such circumstances, nor in such detail. It does however include qualitative provisions favouring broadleaved species. The Swedish FSC standard elaborates on the latter, defining quantitative thresholds for the retention of broadleaves (Table 5).

Lithuanian and Swedish legislation differs remarkably in the regulation of final cuttings. Minimum allowable rotation ages in Lithuania are inferred from the aim to maximise the yield of sawlogs (technical maturity) on an average site for the species. The Swedish rotations may not be shorter than the age of maximum annual increment of the stand (quantitative maturity), and depend on site productivity. On typical sites for species this results in remarkably lower allowable felling ages, compared with Lithuania. The rationale is that a forest owner should have large degree of freedom when making harvesting decisions, depending on her/his personal preferences and the market situation. The Lithuanian Cutting Regulations of 2010 additionally introduced several environmental requirements, including quantitative prescriptions for leaving biodiversity trees and deadwood on the clear cuts. Similar provisions are given in the Swedish national FSC standard, but absent in the Swedish legislation (Table 5). 
Table 5. Selected stipulations for forest management measures in commercial forests

\begin{tabular}{|c|c|c|c|}
\hline & Lithuanian legislation & Swedish legislation & Swedish FSC standard \\
\hline $\begin{array}{l}\text { REGENERATION: } \\
\text { Max. time to } \\
\text { regenerate forest }\end{array}$ & $\begin{array}{l}\text { Normally } 3 \text { years; in case of } \\
\text { calamities, } 2 \text { years after the } \\
\text { stand loss is recorded. }\end{array}$ & $\begin{array}{l}3 \text { years; sufficient } \\
\text { number of naturally } \\
\text { regenerated trees within } \\
5 \text { years. }\end{array}$ & 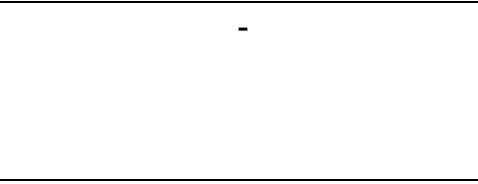 \\
\hline \multirow[t]{4}{*}{ THINNINGS } & \multirow{2}{*}{$\begin{array}{l}\text { Detailed stipulations of } \\
\text { thinning regimes, generally } \\
\text { disfavouring "non-noble” } \\
\text { broadleaved species, including } \\
\text { aspen, alder (Alnus spp.) and } \\
\text { birch (Betula spp.). }\end{array}$} & \multirow{2}{*}{$\begin{array}{l}\text { Silvicultural measures } \\
\text { shall not turn a } \\
\text { broadleaf stand ( } \geq 70 \% \\
\text { of broadl. or } \geq 50 \% \text { of } \\
\text { noble broad.) into non- } \\
\text { broadleaf stand. }\end{array}$} & $\begin{array}{l}\text { Estates should be managed so } \\
\text { that, over time: }\end{array}$ \\
\hline & & & $\begin{array}{l}\geq 5 \% \text { of mesic \& moist } \\
\text { forestland carries broadleaf- } \\
\text { dominated stands }\end{array}$ \\
\hline & \multirow{2}{*}{$\begin{array}{l}\text { Precommercial thinnings } \\
\text { prohibited in April-June, } \\
\text { commercial thinnings in May- } \\
\text { July }\end{array}$} & \multirow{2}{*}{$\begin{array}{l}\text { Admixture of } \\
\text { broadleaves to be } \\
\text { maintained in conifer } \\
\text { stands }\end{array}$} & $\begin{array}{l}\text { spruce-dominated stands take } \\
\leq 50 \% \text { (in nemoral zone) }\end{array}$ \\
\hline & & & $\begin{array}{l}\text { broadleaves make up } \geq 10 \% \\
\text { of a stand at final felling. }\end{array}$ \\
\hline
\end{tabular}

FINAL FELLINGS

Minimum allowable

rotation age Pine: 101

(species: years) Spruce: 71

Birch: 61

Clear cut area, ha Oak: 121
Pine: 60-90

Spruce: $45-90$

Birch: 35

Oak: 90

Biodiversity trees $\& \leq 8$ ha

dead wood to be left

on clear felling $\quad \geq 7$ living trees on sites of $\geq 1$ ha

sites, (all per $1 \mathrm{ha}$ ) (3 of these older or thicker than stand average)

$\geq 3$ dead trees (or high stumps),

$\mathrm{D} \geq 20 \mathrm{~cm}$

$\geq 5 \mathrm{~m} 3$ of logging residuals or

additional biodiversity trees of

equivalent volume.

OTHER

SELECTED

STIPULATIONS
Non-clear final felling required On estates $\geq 50 \mathrm{ha}$, final in case of sufficient undergrowth or 2nd layer of target species.

Stands next to new clearcut cannot be clearcut sooner than after 4-10 y., (depend. on species \& site).

Detailed allowable cut requirements depending on the size of estate fellings should not be conducted in such a way area on dry and that forest under 20 years age occupies more than $50 \%$ of productive forestland. at least $5 \%$ of regeneration area on dry and mesic sites. Avoiding harvesting operations in broadleaf- $\geq 10$ wind resistant live trees of different species

$\geq 2$ coarse stems when harvesting windthrows creating $\geq 3$ high stumps or girdled trees, striving to select equal numbers of coarse pine, spruce, birch and aspen trees

Reasonable measures to burn dominated stratified forests during bird breeding season. No new ditches for soil drainage on land that has not been ditched.

Sources: FSC Sweden, 2010; LD, 1993; LRS, 2011; MERL, 2008; MERL, 2010a.

Summing up, the Lithuanian legislation puts severer restrictions on forest management activities compared with the Swedish Forest Act. The Swedish FSC standard contains numerous environmental stipulations, many of which are on par with the current legal requirements in Lithuania. In terms of the potential biodiversity impacts, probably the largest difference is in the regulation of minimum allowable rotation ages that, for a typical site for the respective tree species, are from 1.2 (spruce) to 1.7 (birch) times higher in Lithuania. 


\subsection{Forest management practices}

The examination of practices turned out to be the most challenging part in our comparison, because of different perceptions of silvicultural treatments (e.g. what is clear versus non-clear felling), lack of comparable data on major silvicultural interventions (e.g. ages of the actually harvested stands) and generally poorer data on forestry activities than on variables describing forest condition.

To start with, natural forest regeneration represents a considerably higher share of Lithuanian managed forests (Table 6) with a clearly increasing trend over the last two decades. Though it might be discussed to what degree natural regeneration is environmentally superior to planting, it should be noted that Norway spruce overwhelmingly dominates the artificial regeneration of Götaland. According to NFI records, the share rose from around $70 \%$ in late 1980 s, to over $75 \%$ in 1990 s, to approximately $85 \%$ of all artificial regeneration during the first decade of this century. Broadleaves and species mixtures are considerably more common in naturally regenerated stands, creating better starting points for developing more heterogeneous stands. Such trajectories are further enhanced in later stages of stand development. When thinnings are less intensive, as it is in Lithuania (SKS, 2011; MERL, 2010b), generally a lower share of broadleaves are eliminated from conifer stands.

Table 6. Common current practices and trends

\begin{tabular}{|c|c|c|c|c|}
\hline \multirow{2}{*}{ (n) } & \multicolumn{2}{|c|}{ Lithuania } & \multicolumn{2}{|c|}{ Southern Sweden } \\
\hline & status $^{1}$ & trend $^{3}$ & status ${ }^{2}$ & trend $^{3}$ \\
\hline \multicolumn{5}{|l|}{ FOREST REGENERATION, 2004-2008 } \\
\hline - \% natural regeneration & $50 \%$ & $\pi$ & $31 \%$ & $\pi$ \\
\hline - \% of regeneration area as broadleaves & $43 \%$ & $\pi$ & $7 \%$ & $\rightarrow$ \\
\hline - \% spruce area in artificial regeneration & $75 \%$ & y & $85 \%$ & $\eta$ \\
\hline - \% exotic species area in regeneration & $0.0002 \%$ & $y$ & $2 \%$ & $\pi$ \\
\hline \multicolumn{5}{|l|}{ FINAL FELLINGS } \\
\hline - \% of clear fellings in final fellings & $78 \%$ & y & n.a. & n.a. \\
\hline \multirow[t]{4}{*}{ Average actual rotation ages, years } & Pine: 112 & n.a. & Pine: 90 & n.a. \\
\hline & Spruce: 85 & & Spruce: 75 & \\
\hline & Oak: 143 & & Oak: 115 & \\
\hline & Birch: 73 & & Birch: 55 & \\
\hline $\begin{array}{l}\text { - average size of clear cuts (excluding those }<0.5 \\
\text { ha), ha }\end{array}$ & $1.8 \mathrm{ha}$ & n.a. & $2.6 \mathrm{ha}$ & n.a. \\
\hline Annually fertilised forest area (2010), ha & 0 & $\rightarrow$ & 3400 & $\pi$ \\
\hline $\begin{array}{l}\text { Annual removals of tops and branches, } \\
1.000 \mathrm{~m}^{3} / 1.000 .000 \text { ha }\end{array}$ & 75 & $\pi$ & 503 & $\rightarrow$ \\
\hline Annual area of removed stumps, ha & 0 & $\rightarrow$ & 1.754 & n.a. \\
\hline
\end{tabular}

${ }^{1}$ most recent available data, 2004 and later; most indicators from (SFSS, 2009); clear cut size, fertilised areas and removals of tops, branches and stumps compiled on request at the State Forest Service, based on reports from State forest enterprises and refer to state forests only. ${ }^{2}$ most recent available data, 2005 and later; forest regeneration data compiled on request from data of NFI, share of exotic species estimated by forest owner association Södra; average rotations estimated by experts from the Swedish University of Agricultural Sciences and state forest company Sveaskog; the remaining data from (SKS, 2011).

3The trend indicates the development over last two decades, based on (SFSS, 2003; SFSS, 2009; MFRL, 1993-1996; SKS 2011; TaxWebb, 2011), ad hoc data extractions by the experts of NFI and officers of forest statistics, and estimates by academic experts. 
As to final harvesting, a clear trend in Lithuania is towards an increasing share of non-clear cutting methods currently applied to more than $20 \%$ of harvested area. A straightforward comparison with Southern Sweden is impossible due to a lack of comparable statistics and different definitions of silvicultural methods. As a rough national estimate, the Swedish Forest Agency reported 96\% of felled stands were subjected to clear felling in 2001 (SKS, 2008). Though the available data are imprecise and dated, the share of non-clear cut stands is most likely smaller in Sweden relative to Lithuania. Notably, rotation periods are considerably higher in Götaland than the minimum allowable rotation ages permitted by legislation (Tables 5 and 6). Nevertheless, rotation periods in Lithuania still exceed the average estimates for Southern Sweden by between 10 and 25 years, depending on the tree species considered.

Table 6 shows a sevenfold higher intensity of branch and top removals in Götaland compared with Lithuania. While raising the share of renewable sources in energy production, such reduction of forest biomass is detrimental for biodiversity (Rudolphi and Gustafsson, 2005; Walmsley and Godbold, 2010), and provides an additional indication of the intensity of forest management that takes place in Southern Sweden.

\section{Discussion}

The current state of Swedish and Lithuanian forests is a combined outcome of socio-economic development, associated land-use trajectories and other factors. Among the compared forest condition indicators, stand age and the number of large trees are related to the dynamics of forest utilisation intensity, going back for a half-century and more. The higher proportion of $>70 \mathrm{~cm}$ dbh trees and $>120$ years conifer stands in Southern Sweden can be linked to the fact that heavy forest utilisation in Lithuania lasted until mid 20th century (Brukas and Kairiūkštis, 2003), while in Götaland utilisation peaks are recorded in the second half of the 19 th century (Enander, 2007). However, if the countries will sustain current policies and practices of segregated and integrative management, Lithuania will gradually catch up Southern Sweden in terms of its relative proportion of old stands and large trees.

Other indicators are more sensitive to recent management practices, and most of the selected attributes are indicative of better conditions for biodiversity in Lithuania. The lower share of broadleaved species and mixtures in Sweden is associated with more intensive forestry practices since the middle of the 20th century. Compared with Lithuania, a higher share of forestland in Götaland has been artificially regenerated with conifers, in particular with Norway spruce, and conifers have benefited more from thinning activities (Verbyla et al., 2003; Prof. Urban Nilsson, personal communication). In comparison, less intensive thinning regimes and longer rotations are the most likely factors contributing to higher amount of deadwood in Lithuanian production stands. Current management trends suggest that at least for the immediate future there is likely to be further divergence with respect to these indicators between the studied regions.

With respect to informing relevant strategies for forest management and nature conservation, an important consideration is to what extent the observed trends are outcomes of consciously intended policy for nature conservation. In the case of Lithuania, the current biodiversity value is both an "unintended legacy" of the Soviet period when forest utilisation was low; as well as outcome of recent intended policies and unintended factors.

In the Soviet period, the rationale was to build up what were previously depleted resources, by importing vast amounts of timber from the Russian Federation. This situation quickly reversed upon Lithuania's regaining of independence, with timber harvesting doubling soon afterwards. Despite this increased extraction, Lithuanian commercial forest management is 
still guided by the "management for volume" paradigm, which results in longer rotations and a lower focus on intensive conifer management relative to Sweden. Even if not specifically studied here, we believe this is not driven by an explicit environmental focus, but rather by the "inherited ideal" of maximising the flow of saw-logs. Even from a silvicultural standpoint, this approach results more as product of tradition than as a conscious policy target.

Commercial state forests in Lithuania harbour significant amounts of what silviculturalists consider overmature stands. In addition, the share of natural regeneration is increasing. These trends presumably are a by-product of the current economic model, more than a targeted environmental goal of the state forest enterprises (Brukas et al., 2009; Brukas et al., 2011). Positive environmental outcomes are also resulting from the fact that most private forest owners prefer natural regeneration (now making up two thirds of the regeneration area) over artificial regeneration, and likewise often chose to avoid pre-commercial thinning. Many owners simply rely on letting natural processes operate as long as such processes result in clearance of legal requirements for regeneration rates. Owners are generally not eager to incur the up-front expense of planting, irrespective of its higher economic potential in the long-term.

This is not to suggest that all positive conservation outcomes in Lithuania are distinct from targeted policy initiatives, particularly for the period subsequent to regaining independence. Protected areas and forest areas with substantial management restrictions were significantly expanded during the 1990s. Likewise, recently adopted legislative changes requiring minimum numbers of retention trees at final felling, and seasonal harvesting restrictions, are all policies specifically designed to integrate conservation values with timber production goals (Table 5).

In comparison, the relative importance of "unintended conservation" outcomes is less significant in Sweden. Such outcomes are primarily manifested through the variety of management goals set by private forest owners. Some owners simply prefer not to follow the conventional management for profit paradigm, and instead extend their rotation periods, or chose to increase the area of set-asides or, in some occasions, leave the estates unmanaged. Outside of these exceptions, the bulk of southern Sweden's forests are managed intensively for timber production. With respect to intended conservation policies, a targeted effort was begun two decades ago to increase the share of forest designated for nature conservation, through formal protection or voluntary commitments. The national share of protected areas has correspondingly risen since the 1990s (Angelstam et al., 2011), though the achievements are still modest in Southern Sweden relative to Lithuania. The intended integrative measures, such as minimum required levels of tree retention, or programs to increase the share of broadleaves in timber stands, are mainly implemented through voluntary instruments such as forest certification. Only time will tell whether such voluntary approaches can sustain conservation gains at the larger scale, and whether they provide the expected biodiversity benefits.

It must be noted that our study only treated possible forest management impacts on biodiversity indicators, without examining the economic efficiency, social equity or other socio-economic implications. There are notable differences between countries in the latter aspects, e.g. forest owners in Sweden are usually compensated for forest management restrictions of segregative character whereas this is not the case in Lithuania. While the socioeconomic implications are of great importance, they need to be left for future research. 
To the best of our knowledge, our study is among the first international comparisons that simultaneously and explicitly links segregative and integrative forest management practices with biodiversity conservation. We believe that our set of forest condition indicators and management activities could be readily used for the comparison of other countries in the Baltic Sea region. Despite the fact that Sweden and Lithuania share one of the most advanced NFI designs, data collation and interpretation nevertheless remained difficult. Countries in the region have a great deal to gain from such comparisons with their neighbours, but if such efforts are to be facilitated, it will require an active and systematic effort to harmonize forest condition statistics. We also recommend that more extensive national statistics regarding actual management practices (e.g. average rotation ages) are provided, as this information is vital for assessing potential management impacts on biodiversity and for providing a better information base for future policies. If this can be achieved then similar and more advanced assessments will be increasingly feasible for those willing to work across the disciplines of forest ecology, inventory assessment, management, and policy.

\section{Acknowledgements}

We are grateful to NFI experts whose help was indispensible for extracting harmonised inventory data: Darius Vižlianskas and Andrius Kuliešis in Lithuania as well as Bertil Westerlund and Anders Lundström in Sweden. Special thanks are extended to three anonymous reviewers for careful and helpful comments.

\section{References}

Ahti, T., Haemet-Ahti, L., Jalas, J., 1968. Vegetation zones and their sections in north-western Europe. Annales Botanici Fennici 5, 169-211.

Angelstam, P. K., Anufriev, V. M., Balciauskas, L., Blagovidov, A. K., Borgegard, S. O., Hodge, S. J., Majewski, P., Ponomarenko, S.V., Shvarts, E. A., Tishkov, A. A., Tomialojc, L., Wesolowski, T., 1997. Biodiversity and sustainable forestry in European forests: How East and West can learn from each other. Wildlife Society Bulletin 25, 38-48.

Angelstam, P., Andersson, K., Axelsson, R., Elbakidze, M., Jonsson, B. G., Roberge, J., 2011. Protecting forest areas for biodiversity in Sweden 1991-2010: The policy implementation process and outcomes on the ground. Silva Fennica 45, 1111-1133.

Angelstam, P., Breuss, M., Mikusinski, G., 2001. Toward the assessment of forest biodiversity at the scale of forest management units - A European landscape perspective, in Franc, A., Laroussinie, O., Karajalainen, T. (Eds). Criteria and indicators for sustainable forest managment at the forest management unit level. European Forest Institute, Nancy, pp. 5974.

Balkyte, A., Peleckis, K., 2010. Mapping the future sustainable competitiveness resources: Aspects of forest ownership. Journal of Business Economics and Management 11, 630-651.

Berg, Å., Ehnström, B., Gustafsson, L., Hallingbäck, T., Jonsell, M., Weslien, J., 1994. Threatened plant, animal, and fungus species in Swedish forests: Distribution and habitat associations. Conservation Biology 8, 718-731.

Bitvinskaite, Z., 2011. Darni ir subalansuota miškininkystè. Kas tai? Miškai 22, 41-43.

Brockerhoff, E.G., Jactel, H., Parrotta, J.A., Quine, C.P., Sayer, J., 2008. Plantation forests and biodiversity: oxymoron or opportunity? Biodiversity and Conservation 17, 925-951.

Brukas, A., Kairiūkštis, L. 2003. Miško kirtimai ir bendras naudojimas [Forest cuttings and overall utilisation]. In: Verbyla, V., Brukas, A. Kairiūkštis, L. (Eds.), Lietuvos miškų metraštis XX amžius. Ministry of Environment, pp. 181-187.

Brukas, V., Kuliešis, A., Sallnäs, O., Linkevičius, E., 2011. Resource availability, planning rigidity and Realpolitik in Lithuanian forest utilization. Natural Resources Forum 35, 77-88.

Brukas, V., Linkevičius, E., Činga, G., 2009. Policy drivers behind forest utilization in Lithuania in 1986-2007. Baltic Forestry 15, 86-96. 
Brukas, V., Sallnäs, O., 2012. Forest management plan as a policy instrument: carrot, stick or sermon? Land Use Policy 29, 605-613.

Brukas, V., Weber, N., 2009. Forest management after the economic transition-at the crossroads between German and Scandinavian traditions. Forest Policy and Economics 11, 586-592.

Bush, T., 2010. Biodiversity and sectoral responsibility in the development of Swedish forestry policy, 1988-1993. Scandinavian Journal of History 35, 471-498.

Carnus, J.M., Parrotta, J., Brockerhoff, E., Arbez, M., Jactel, H., Kremer, A., Lamb, D., O’Hara, K., Walters, B., 2006. Planted forests and biodiversity. Journal of Forestry 104, 65-77.

Chirici, G., Winter, S., McRoberts, R.E. (Eds.) 2011. National forest inventories: Contributions to forest biodiversity Aasessments, Springer, Dordrecht Heidelberg London New York.

Corona, P., Marchetti, M., 2007. Outlining multi-purpose forest inventories to assess the ecosystem approach in forestry. Plant Biosystems 141, 243-251.

Duinker, P.N., 2001. Criteria and indicators for sustainable forest management in Canada: progress and problems in integrating science and policy at the local level. In: Franc, A., Laroussinie, O., Karjalainen, T. (Eds.), Criteria and Indicators for Sustainable Management at the Forest Management Unit Level. EFI Proceedings 38, 7-27.

Enander, K.G., 2007. Skogsbruk på samhällets villkor. Skogsskötsel och skogspolitik under 150 år. Swedish University of Agricultural Sciences, Report 1, Umeå.

Felton, A., Lindbladh, M., Brunet, J., Fritz., O., 2010. Replacing coniferous monocultures with mixed-species production stands: An assessment of the potential benefits for forest biodiversity in northern Europe. Forest Ecology and Management 260, 939-947.

Fritz, O., Niklasson, M. and Churski, M. 2009. Tree age is a key factor for the conservation of epiphytic lichens and bryophytes in beech forests. Applied Vegetation Science 12, 93-106.

FSC Sweden, 2010. Swedish FSC Standard for Forest Certification including SLIMF indicators. V2-01 050510, Uppsala.

Gustafsson, L., Perhans, K., 2010. Biodiversity conservation in Swedish forests: Ways forward for a 30-year-old multi-scaled approach. Ambio. A Journal of the Human Environment 39, 546554.

Hartmann, H., Daoust, G., Bigue, B., Messier, C. 2010. Negative or positive effects of plantation and intensive forestry on biodiversity: A matter of scale and perspective. Forestry Chronicle 86, 354-364.

Hesselman, H., Schotte, G., 1906. Granen vid sin sydvästra gräns i Sverige. Meddelanden från Statens skogsförsöksanstalt, H.3,1-52.

Hjortso, C. N., Straede. S., 2001. Strategic multiple-use forest planning in Lithuania - applying multi-criteria decision-making and scenario analysis for decision support in an economy in transition. Forest Policy and Economics 3, 175-188.

Jansson, G., Angelstam, P., 1999 Threshold levels of habitat composition for the presence of the long-tailed tit (Aegithalos caudatus) in a boreal landscape. Landscape Ecology 14, 283-290.

Jonsell, M., Weslien, J., Ehnstrom, B., 1998. Substrate requirements of red-listed saproxylic invertebrates in Sweden. Biodiversity and Conservation 7, 749-764.

Jonsson, B.G., Kruys, N., (Eds.), 2001. Ecology of woody debris in boreal forests. Ecological Bulletins 49.

Jonsson, B.G., Kruys, N., Ranius, T., 2005. Ecology of species living on dead wood - Lessons for dead wood management. Silva Fennica 39, 289-309.

Kabailienè M. 2006. Late Glacial and Holocene stratigraphy of Lithuania based on pollen and diatom data. Geologija 54, 42-48.

Kouki, J., Arnold, K., Martikainen, P., 2004. Long-term persistence of aspen - a key host for many threatened species - is endangered in old-growth conservation areas in Finland. Journal for Nature Conservation 12, 41-52.

KSLA (Royal Swedish Academy of Agriculture and Forestry), 2009. The Swedish forestry model. Stockholm. 
Kurlavicius, P., Kuuba, R., Lukins, M., Mozgeris, G., Tolvanen, P., Angelstam, P., Karjalainen, H., Walsh, M., 2004. Identifying High Conservation Value Forests in the Baltic States from Forest Databases. Ecological Bulletins 51, 351-366.

Lazdinis, M., Carver, A., Lazdinis, I, Paulikas, V.K., 2009. From union to union: forest governance in a post-soviet political system. Environmental Science and Policy 12, 309-320.

LD (Landsbygdsdepartementet). 1993. Skogsvårdsförordning [Forestry Act]. Ministry of Rural Affairs, 1993:1096.

Liira, J., Sepp, T., Parrest, O., 2007. The forest structure and ecosystem quality in conditions of anthropogenic disturbance along productivity gradient. Forest Ecology and Management 250, 34-46.

Lindbladh, M., and Foster, D.R. 2010. Dynamics of long-lived foundation species: the history of Quercus in southern Scandinavia. Journal of Ecology 98, 1330-1345.

Lindenmayer, D.B., Hobbs, R.J., 2004. Fauna conservation in Australian plantation forests-a review. Biological Conservation 119, 151-168.

Lindenmayer, D.B., Margules,C.R., Botkin, D.B., 2010. Indicators of biodiversity for ecologically sustainable forest management. Conservation Biology 14, 941-950.

LRS (Lietuvos Respublikos Seimas) 2011. Lietuvos Respublikos Miškų įstatymas [Forest Act of the Lithuanian Republic]. Vilnius.

LSD (Lietuvos Statistikos Departamentas). 2011. Išankstiniai 2011 metų gyventojų surašymo rezultatai pagal apskritis ir savivaldybes. Pranešimas spaudai Nr. 18.

Maciejewski, W., (Ed.), 2002. The Baltic Sea Region - Cultures, Politics, Societies. Baltic University Press, Uppsala.

Martikainen, P., Siitonen, J., Punttila, P., Kaila, L., Rauh, J., 2000. Species richness of Coleoptera in mature managed and old-growth boreal forests in southern Finland. Biological Conservation 94, 199-209.

McElhinny, C., Gibbons, P. Brack, C., Bauhus, J., 2005. Forest and woodland stand structural complexity: Its definition and measurement. Forest Ecology and Management 218, 1-24.

MERL [Ministry of Environment of the Republic of Lithuania]. 2007. Miško dauginamosios medžiagos nuostatai [Regulations for forest planting material]. Nr. D1-651, Vilnius

MERL [Ministry of Environment of the Republic of Lithuania]. 2008. Dèl miško atkūrimo ir ivveisimo nuostatų [Concerning Regulations of Reforestation and Afforestation]. Nr. D1-199, Vilnius.

MERL [Ministry of Environment of the Republic of Lithuania]. 2010a. Miškų kirtimo taisyklès [Regulations of Forest Cutting] Nr. D1-79, Vilnius.

MERL [Ministry of Environment of the Republic of Lithuania]. 2010b. Lithuanian statistical yearbook of forestry, Kaunas.

MERL [Ministry of Environment of the Republic of Lithuania]. 2011. Lithuanian statistical yearbook of forestry, Kaunas.

MFRL [Ministry of Forestry of the Republic of Lithuania]. 1993-1996. Miškų ūkio įmonių 19921993 gamybinès veiklos rodikliai. Unksna, Vilnius.

Naturvårdsverket, 2012: Steg på vägen. Fördjupad utvärdering av miljömålen 2012 [On the way. In depth evaluation of environmental objectives 2012]. Rapport 6000, Stockholm.

Nilsson, S.G., Hedin, J., Niklasson, M., 2001. Biodiversity and its assessment in boreal and nemoral forests. Scandinavian Forest Research Supplements 3, 10-26.

Ohlson, M., Söderström, L., Hörnberg, G., Zackrisson, O., Hermansson, J., 1997. Habitat qualities versus long-term continuity as determinants of biodiversity in boreal old-growth swamp forests. Biological Conservation 81, 221-231.

Roberge, J.M., Angelstam, P., 2004. Usefulness of the umbrella species concept as a conservation tool. Conservation Biology 18 , 76-85.

Rudolphi, J., Gustafsson, L., 2005. Effects of forest-fuel harvesting on the amount of deadwood on clear-cuts. Scandinavian Journal of Forest Research 20, 235-242. 
Satkūnas, J. (Ed.). 2011. Aplinkos būkle 2010. Tik faktai [Status of environment 2010. Only facts). Lutute, Vilnius.

Schlyter, P., Stjernquist, I., Bäckstrand, K. 2009. Not seeing the forest for the trees? The environmental effectiveness of forest certification in Sweden. Forest Policy and Economics 11, 375-382.

SFSS (State Forest Survey Service) 2003. Lithuanian national forest inventory 1998-2002. Forest resources and their dynamics. Kaunas.

SFSS (State Forest Survey Service) 2009. Lithuanian national forest inventory 2004-2008. Forest resources and their dynamics. Kaunas.

SKS (Skogsstyrelsen) 2008. Regionala analyser om kontinuitestsskogar och hyggesfritt skogsbruk. Skogsstyrelsen, Rapport 7. SJV, Jönköping.

SKS (Skogsstyrelsen). 2009. Swedish Statistical Yearbook of Forestry. Swedish Forest Agency, Tabergs Tryckeri AB, Taberg.

SKS (Skogsstyrelsen). 2011. Swedish Statistical Yearbook of Forestry. Swedish Forest Agency, NRS Tryckeri AB, Huskvarna.

SMHI (Sveriges meteorologiska och hydrologiska institute), 2012. Klimatdata. Hyperlink: www.smhi.se/klimatdata (accessed on September 1, 2012)

Stančikaitè, M., Kisielienė, D., Strimaitienè, A. 2004. Vegetation response to the climatic and human impact changes during the Late Glacial and Holocene: case study of the marginal area of Baltija Upland, NE Lithuania. Baltica 17, 17-33.

Statistiska centralbyrån, 2011. Folkmängd i landskapen den 31 december 2010. Accessed on September 4, 2012.

TaxWebb, 2011. An interactive web service for queries and data tabulation from the Swedish National Forest Inventory (in Swedish). Swedish University of Agricultural Sciences. Hyperlink: www-taxwebb.slu.se (Accessed in September-October 2011)

Toet, H., Fridman, J., Holm, S. 2007. Precision in estimates from National Forest Survey 19982002. Arbetsrapport 167:2007, Institutionen för skoglig resurshushållning, SLU, Umeå.

Tomppo, E., Gschwantner, Th., Lawrence, M., McRoberts, R.E., (Eds.) 2010. National Forest Inventories - Pathways for common reporting. Springer.

Verbyla, V., Brukas, A., Kairiūkštis, L., (Eds.). 2003. Lietuvos miškų metraštis XX amžius. Ministry of Environment, Vilnus.

Walmsley, J. D., Godbold, D.L., 2010. Stump harvesting for bioenergy - A review of the environmental impacts. Forestry 83, 17-38. 